\title{
The Variation of Head Shapes in 17-20 Years Old Native Fars Male in Gorgan-North of Iran
}

\author{
Variaciones en las Formas de la Cabeza en Hombres Nativos Fars \\ entre 17-20 Años en Gorgan-Norte de Irán
}

Mohammad Jafar Golalipour

GOLALIPOUR, M. J. The variation of head shapes in 17-20 years old native Fars male in Gorgan-North of Iran. Int. J. Morphol., 24(2):187-190, 2006.

SUMMARY: Cephalic index and head shape are affected by geographical, gender, age and racial factors. This study carried out to determine cephalic index and head shape in 17-20 years old native Fars male in Gorgan, North of Iran. This descriptive study was done on 200 of 17-20 years old male native Fars by classic cephalometry in Gorgan, North of Iran.

Mean and SD of cephalic index was $84.8+6.9$. The head shape of $52 \%$ of individuals was hyperbrachycephalic, $25 \%$ brachycephalic, $21.5 \%$ mesocephalic and $1.5 \%$ dolichocephalic. Native Fars individuals showed typical hyperbrachycephalic. In comparing to other studies in world, we can conclude that the role of racial/ethnic factor in cephalic diameters.

KEY WORDS: Craniofacial forms; Cephalometry; Cephalic index; Prosopic index; Male.

\section{INTRODUCTION}

The evaluation and measurement of human body dimensions are achieved by physical anthropometry (Chamela 1997, Williams et al., 1995). Cephalometry is one of the important parts of anthropometry in which dimensions of head and face are measured. Cephalometric results are used in pediatrics, forensic medicine, plastic surgery, oral surgery dentistry, and diagnostic comprehension between patient and normal populations (Williams et al.).

The human body dimensions are affected by ecological, biological, geographical, racial, gender and age factors (Golalipour et al., 2003, Okupe et al., 1984, Tuli et al., 1995, Rajlakshmi et al., 2001).

On the basis of above factors, anthropometric studies are conducted on the age, sex and racial groups in certain geographical zones (Williams et al. and del Sol, 2005).

The most important of cephalometric dimension are height and weight of head that with using of them we can determine cephalic index.

On basis of cephalic index head shapes classified four international categories, that including dolicocephal, brackiocephal, mesocephall and hyperbrakicephal (Williams et al. and del Sol).

A few investigations determined the types of head shape in various ages in Iran and other countries (Avicenna 1984; Jorjani, 1975; del Sol; Shah \& Jadhav, 2004; Jordaan 1976 and Golalipour et al.).

By noticing, the effect of racial, ethnic and geographical factors on head dimensions and lack of documented research in this area, for the first time, this study was done to determine the cephalic index and types of head shapes in 17-20 years old native Fars male in Gorgan- north of Iran.

\section{MATERIAL AND METHOD}

This research descriptive and cross- sectional was done on 200, 17-20 years old normal native Fars males in Gorgan- North of Iran. 
Native Fars group is main and original in habitants of this region and populations of native Fars have been selected last three generations who lived in this zone.

All the measurements were taken with the subject sitting in chair, in relaxed condition and head in anatomical position.

Head measurements, which were determined by Martin spreading caliper, were included:

Head length $=$ Summit of glabella to furthest occipital point . Head width $=$ greates breadth, at right angles to median plane .

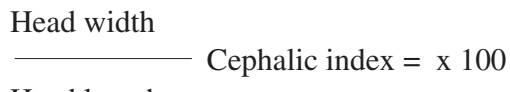

Head length

Above index was determined on the basis of international anatomical descriptive (Williams et al.).

Depending upon this index the types of head and face shapes were followed as (Williams et al.):

$\begin{array}{lc}\text { Head shape } & \text { Cephalic index }(\mathrm{CI}) \text { range }(\%) \\ \text { Dolichocephalic } & \mathrm{CI}<74.9 \\ \text { Mesochepalic } & 75<\mathrm{CI}<79.9 \\ \text { Brachycephalic } & 80<\mathrm{CI}<84.9 \\ \text { Hyperbrachycphalic } & 85<\mathrm{CI}<89.9 \text { and } \mathrm{CI}<89.9\end{array}$

The data for each person was recorded in a special form and then analyzed by EPI6.

\section{RESULTS}

Mean and SD of cephalic index in native Fars group was $84.8 \pm 6.9$. Head was classified by cephalic index, so that hyperbrachycephalic type with $52 \%$ was dominated. Also the $25 \%$ of the individuals were brachycephalic, $21.5 \%$ mesocephalic and $1.5 \%$ dolichocephalic (Table I).

Table I. Distribution of head shapes in native Fars male 17- 20 years old.

\begin{tabular}{lc}
\hline Head shape & Number (percent) \\
\hline Dolichocephalic & $3(1.5)$ \\
Mesocephalic & $43(21.5)$ \\
Brachycephalic & $50(25.0)$ \\
Hyperbrachycephalic & $104(52.0)$ \\
\hline
\end{tabular}

\section{DISCUSSION}

In this study cephalic index was 84 . The cephalic index was higher than others study such as, in Tehran- center of Iran with 75 (Abolhasanzadeh \& Farahani, 2003), India with 80.42 (Shah \& Jadhav), and in Chile with 80.42 (del Sol).

Cephalic index was determined in Chile with average of $81.51 \pm 0.46$, Also, cephalic index reported $81.19 \pm$ 0.05 in European people in Mediterranean area, and $79.72 \pm$ 0.97 in north of Europe ( apud García \& Lips 1986a,b).

In our study, dominant type of head shape was hyperbrachycephalic (52\%). This finding is not similar to another study in Iran (Abolhasanzadeh \& Farahani), that the dominant type was brachycephalic (36.6\%). Also, dominant type of head from this study is not similar to other study, in India (Bhatia et al., 1955) with dolicocephal (58.5\%), and del sol study in Chile and (Marquer \& Chamela, 1961) that mesocephal type was dominant type.

Bathia et al., on 806 samples in India, reported that $58.5 \%$ of the individuals were dolichocephalic, $19.2 \%$ hyperdolicocephalic, $21 \%$ mesocephalic and less than $1 \%$ of them were brachycephalic.

Also, del Sol on 50 adult's male in the IX Region of Chile, reported that $66 \%$ of the individuals were mesocephalic, $28 \%$ brachycephalic, $4 \%$ hyperbrachycephalic and $2 \%$ dolichoephalic.

Abolhasanzadeh \& Farahani on 953 adult male (2224 years old) in Tehran- Iran reported that $36.6 \%$ of the individuals were brachycephalic, $29.9 \%$ hyperbrachycephalic, $24.5 \%$ mesocephalic and 9\% dolichocephalic.

Shah \& Jadhav on 302 male students reported that $41 \%$ of students were mesocephal and $37 \%$ brachycephal. The some centuries age, the some studies were done by two famous scientists in Iran, are very interesting (Avicenna and Jorjani).

More than eleven centuries ago, Avicenna \& Jorjani reported that the dominant type of head shape in Iranian people were mesocephal (Avicenna \& Jorjani), But recent studies in Iran, showed that the dominant type were hyperbrachycephalic or brachycephalic.

Therefore, we concluded that there is a trend change in head shapes of Iranian people and the dominate type of head shape changed from mesocephalic to brachycephalic and hyperbrachycephalic. 
Other study has shown changes of head shape (brachycephalization) during 30 years on population (Nakashima, 1986).

In respect to the variation of head shape in various races, ethnic and geographical zones, we believe that inhereditary factor primarily affects on the shape of head, however environment has secondary effect on it.

It must be remembered that the reaction to a given environment represents the interaction of the genotype of the population being studied with the environment (Jordaan).
With noticing to present study and other studies in Iran we can conclude that trend of brachycephalization and hyperbrachycephalization was happened during some centuries on consequents generations of people.

\section{ACKNOWLEDGEMENTS}

We appreciate the research deputy of Gorgan University of Medical Sciences, and Mr. K. Heidari, Mr. M. Jahanshahi and Mr M.A.Vakili for statistical analysis and Special thanks to Miss Soraya Ghafari.

GOLALIPOUR, M. J. Variaciones en las formas de la cabeza en hombres nativos Fars entre 17-20 años en Gorgan, Norte de Irán. Int. J. Morphol., 24(2):187-190, 2006.

RESUMEN: El índice cefálico y la forma de la cabeza son afectados por factores geográficos, género, edad y raza. El objetivo de este estudio fue determinar el índice cefálico y la forma de la cabeza en 200 hombres nativos de Gorgan-Norte de Irán, cuyas edades fluctuaban entre 17 y 20 años de edad. El estudio descriptivo fue realizado a través de cefalometría clásica.

La media y DS del índice cefálico fue $84.8+6.9$. El 52\% de los individuos era hiperbraquicéfalo, $25 \%$ braquicéfalo, $21.5 \%$ mesocéfalo y $1.5 \%$ doliocéfalo. Los individuos nativos Fars eran típicamente hiperbraquicéfalos. En comparación con otros estudios efectuados en el mundo, podemos determinar el rol del factor racial/étnico en los diámetros cefálicos.

PALABRAS CLAVE: Formas craneofaciales; Cefalometría; Indice cefálico; Hombre.

\section{REFERENCES}

Abolhasanzadeh, A. \& Farahani, M.R. Standarded international classification of head shapes of 22-24 years old in Tehran. J. of Research in medicine, 26(4):281-5, 2003.

Avicenna Sh. R. Law in medicine (Ghanon dar teb). Translated to persian (Farsi) by Sharafkandi, A. Sorosh Publisher co., Tehran, 1984. V. 1. p. 57.

Bhatia, M.; Thin, J.; Debray, H. \& Cabanes, J. Etude anthropologique et genetique de la population du Nord de 1'Inde. Bull. Et Mem Soc. d'anthrop. de Paris, 10(6):199-213,1955.

Chamela, M. Biological antropology. Translated to Persian (Farsi) by Nadri A. First Edn. Gostav Publisher, Tehran, 1997. p. 75.

Del sol, M. Cephalic index in a group of mapuche individuals in the IX Region of Chile. Int. J. Morphol., 23(3):241-6, 2005.

García, H. F. \& Lips, M.W. Contribución al studio delíndice cefálico en chilenos. An. Anat. Normal, 4:120-3,1986a.
Garcia, H. F. \& Lips, M.W. Variaciones del índice cefálico en chilenos según ascendencia. An. Anat. Normal, 4:1179, 1986b.

Golalipour, M. J.; Haidari, K.; Jahanshahi, M. \& Frahani, M.R. The shapes of head and face in normal male newborns in south-east of Caspian Sea (Iran-Gorgan). $J$ Anat Soc. India, 52:28-31, 2003.

Jordaan, H.V. Neonatal and maternal cranial form. S. Afr. Med. J., 4(52):2060-8, 1976.

Jorjani, S. I. Zakhireye Khrazmshahi. Translated to Persian by: Sirjani Saidi. Iranian cultural institute. Tehran, 1975.

Marquer, P.; Chamela, M. C. L'evolution des caracteres morphologiques en function de l'age, chez 2089 fracais, de 20 a 91 ans. Bull. et Mem Soc. d'anthrop. de Paris, 11(2):1-78, 1961.

Nakashima, T. Brachycephalization in the head form of school girls in north kyuoshu. Sangyo. Ika Dainguku Zussshi. 8(4):411-4, 1986. 
Okupe, R. F.; Cooker, O. O. \& Gbajumo, S. A. Assessment of fetal biparital diameter during normal pregnancy by ultrasound in Nigerian women. British J. of Obstetrics and Gynecology, 99:629-32, 1984.

Rajlakshmi, C. H.; Shyamo Singh, M.; Bidhumukhi, T. H. $\&$ Chandramani Singh L. Cephalic index of foetuses of manipuri population - A Baseline study. J. Anat. Soc. India, 50(1):13-6, 2001.

Shah, G.V. \& Jadhav, H.R. The study of cephalic in students of Gujarat. J. Anat. Soc. India. 53(1):25-6, 2004.

Tuli, A.; Choudhry, R. ;Agarwal, S.; Anand, C. \& Gary, H. Correlation between craniofacial dimensions and foetal age. J. Anat Soc. India. 44(1):1-12, 1995.

Williams, P.; Dyson, M.; Dussak, J. E.; Bannister, L. H.; Berry, M. M. ;Collins, P. \& Ferguson, M.W.J: Gray's Anatomy. In: Skeletal system. $38^{\text {th }}$ Edn. Elbs with Churchill Livingston. London, 1995. pp. 607-612.
Correspondence to:

Dr. Mofiammad Jafar Golalipour,

Department of Anatomy,

Gorgan University of Medical Sciences,

P.O. Box: $49175-553$

Gorgan

IRAN

TEL : +98(171) 4421660,

Fax: +98(171)4421657,

Email:mjgolalipour@yahoo.com

Received : 19-12-2005

Accepted: 08-03-2006 